\title{
ESTUDOS SOBRE O COMPONENTE ORC1/CDC6 DA MAQUINARIA DE PRÉ-REPLICAÇÃO DOS TRIPANOSSOMAS
}

Tese apresentada ao Programa de Pós-graduação em Biologia da Relação Patógeno-Hospedeiro do Instituto de Ciências Biomédicas da Universidade de São Paulo, para obtenção do Título de Doutor em Ciências.

Área de Concentração: Biologia da Relação Patógeno-Hospedeiro.

Orientadora: Maria Carolina Q. B. Elias Sabbaga. 


\section{RESUMO}

Godoy PDM. Estudos sobre o componente Orc1/Cdc6 da maquinaria de pré-replicação dos tripanossomas [Tese (Doutorado em Parasitologia)]. São Paulo: Instituto de Ciências Biomédicas da Universidade de São Paulo; 2010.

Em eucariotos unicelulares como Saccharomycea cerevisiae, e em organismos multicelulares, a origem de replicação é reconhecida pelo complexo de pré-replicação formado por um complexo denominado ORC (Origin Recognition Complex), as proteínas Cdc6 e Cdt1 e o heterohexâmero MCM (MiniChromosome Mainteinance). Já em organismos do domínio Archaea, a origem de replicação é reconhecida por uma proteína Orc1/Cdc6, que apresenta similaridade com Orc1 e Cdc6, e pelo homohexâmero MCM. De forma semelhante à Archaea, os genomas dos tripanossomatídeos contêm somente um gene que codifica para uma proteína anotada como Orc1. Dada a similaridade entre Orc1 e Cdc6, esta proteína foi por nós denominada Orc1/Cdc6. Nesta tese serão descritos os estudos realizados sobre o componente Orc1/Cdc6 da maquinaria de préreplicação do Trypanosoma cruzi e do Trypanosoma brucei. As proteínas recombinantes de T.cruzi (TcOrc1/Cdc6) e de T.brucei (TbOrc1/Cdc6) foram expressas e ambas proteínas apresentam atividade de ATPase, típica da maquinaria de pré-replicação. As proteínas recombinantes de T.brucei e T.cruzi são capazes de substituir Cdc6, mas não Orc1 em ensaio de complementação em leveduras. A indução do silenciamento do gene de Orc1/Cdc6 por RNAi resulta em células anucleadas com quantidade de DNA equivalente ao estado G1 do ciclo celular, o que sugere fortemente o envolvimento de Orc1/Cdc6 na replicação. Estes resultados sugerem que a maquinaria de pré-replicação dos tripanossomas é diferente daquela encontrada nos demais eucariotos e mais semelhante à de Archaeas. Orc1/Cdc6 é expressa durante todo o ciclo celular das formas replicativas dos tripanossomas, permanecendo associada à cromatina em todas as fases do ciclo celular. No caso do T.cruzi, a proteína Orc1/Cdc6 é expressa não só nas formas replicativas, amastigotas e epimastigotas, mas também nas formas não replicativas tripomastigotas e tripomastigotas metacíclicos. Nas formas não replicativas, a proteína expressa interage fracamente com o DNA. Como o primeiro passo do processo de replicação é a interação da proteína Orc1/Cdc6 com DNA, este resultado sugere que a ausência da interação Orc1/Cdc6DNA deve contribuir para ausência da duplicação do DNA nas formas infectivas do T. cruzi.

Palavras-chave: Orc1/Cdc6. ATPase. Pré-replicação. DNA. Tripanossomas. 


\begin{abstract}
Godoy PDM. Studies of the Orc1/Cdc6 component of pre-replication machinery of trypanosomes. [PhD Thesis (Parasitology)]. São Paulo: Instituto de Ciências Biomédicas da Universidade de São Paulo; 2010.
\end{abstract}

In unicellular eukaryotes, such as Saccharomyces cerevisiae, and in multicellular organisms, the replication origin is recognized by a pre-replication machinery composed by a complex called ORC (Origin Recognition Complex), two proteins named Cdc6 and Cdt1 and the heterohexamer MCM complex (Mini Chromosome Mainteinance). However, in members from Archaea domain the replication origin is recognized by just one protein, Orc1/Cdc6; whose sequence is highly related to Orc1 and Cdc6, and by the homohexamer MCM complex. Similar to Archaea, trypanosomatid genomes contain only one gene encoding a protein annotated as Orc1. Since trypanosome Orc1 is also homologous to Cdc6, we named it Orc1/Cdc6. Here we show that the recombinant Orc1/Cdc6 from T.cruzi (TcOrc1/Cdc6) and from T.brucei (TbOrc1/Cdc6) present ATPase activity, typical of pre-replication machinery components. Also, TcOrc1/Cdc6 and TbOrc1/Cdc6 replaced yeast Cdc6 but not Orc1 in a phenotypic complementation assay. The induction of Orc1/Cdc6 silencing by RNA interference in T.brucei resulted in enucleated cells, strongly suggesting the involvement of Orc1/Cdc6 in DNA replication. Taken together, these results allowed us to conclude that Orc1/Cdc6 is indeed a member of the trypanosome prereplication machinery and point out that trypanosomes pre-replication machinery is less complex than other eukaryotes and closer to Archaea. Orc1/Cdc6 is expressed during the entire cell cycle and in all stages of the life cycle in the nuclei of trypanosomes, remaining associated with chromatin in all stages of the cell cycle. This association is different among the stages from $T$. cruzi life cycle. In trypomastigote and metacyclic trypomastigote forms, the non replicative ones, Orc1/Cdc6 does not interact, or weakly interact, with DNA. The lack of pre-replication machinery-DNA interaction in $T$. cruzi non-replicative stages might contribute to the absence of DNA replication in these stages.

Keywords: Orc1/Cdc6. ATPase. Pre-replication. DNA. Trypanosomes. 


\section{INTRODUÇÃO}

Esta tese pretende divulgar as descobertas sobre o componente Orc1/Cdc6 da maquinaria de pré-replicação dos tripanossomas. O assunto será introduzido com uma breve descrição sobre os modelos de estudos utilizados, Trypanosoma brucei e Trypanosoma cruzi, importantes agentes etiológicos de doenças. Na seqüência, os mecanismos que compreendem a replicação do DNA serão descritos, bem como o envolvimento do componente Orc1/Cdc6, objeto desta pesquisa, neste processo.

\subsection{TRIPANOSSOMAS}

Os tripanossomas são organismos que pertencem ao Reino Protista, a ordem Kinetoplastida e a família Trypanosomatidae. São eucariotos, unicelulares, flagelados, parasitas de plantas, invertebrados e vertebrados. Diferem de outros organismos flagelados do mesmo filo por possuírem, além das organelas características do domínio eucarioto, uma única mitocôndria, que se ramifica por toda a célula, e uma bolsa flagelar de onde emerge um flagelo que pode ou não se exteriorizar, dependendo da forma que o protozoário assume (figura 1). Sua mitocôndria apresenta um DNA (kDNA), que se organiza na forma de milhares de minicírculos e dezenas de maxicírculos, que estão concatenados formando uma rede estabilizada por proteínas semelhantes às histonas. Estas proteínas compactam os mini e maxi-círculos dando a forma de disco nesta região da mitocôndria que é denominada de cinetoplasto ou kinetoplasto (Matthews, 2005). 


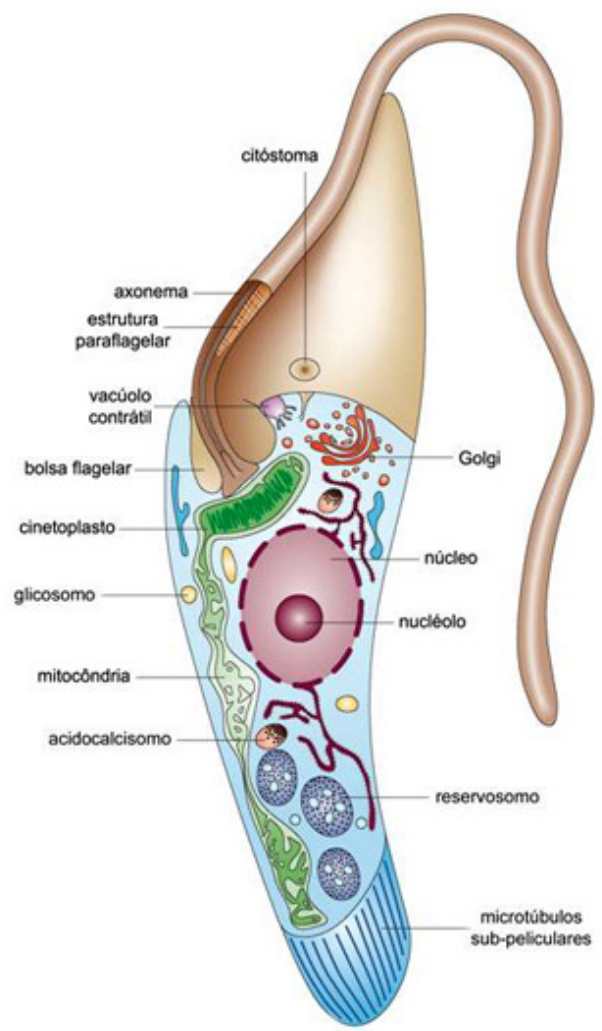

Figura 1- Imagem esquemática do T.cruzi demonstrando as organelas de eucariotos e as estruturas específicas dos tripanossomas.

FONTE: Fundação Oswaldo Cruz (2010).

A família Trypanosomatidae é considerada de grande importância médica e econômica, uma vez que espécies dessa família são capazes de provocar doenças mutilantes, incapacitantes ou mortais (Matthews, 2005). As doenças humanas mais comuns causadas por espécies da família Trypanosomatidae incluem a tripanossomíase Africana humana ou Doença do Sono, a Doença de Chagas e as Leishmanioses. Essas doenças estão intimamente relacionadas ao nível de desenvolvimento do país ou de uma região.

A família Trypanosomatidae se divide em diversos gêneros, destacando aqui Trypanosoma e Leishmania, os quais possuem os mamíferos como principais hospedeiros, incluindo a população humana. Além da importância médica, estes organismos representam um amplo campo de estudos, pois apresentam diversas características que diferenciam os Kinetoplastida em geral dos demais eucariotos.

Somadas às peculiaridades em relação a sua morfologia e fisiologia, destacam-se algumas características moleculares particulares dos tripanossomas. A primeira característica particular 
destes organismos é a presença do cinetoplasto ou kinetoplasto. O DNA contido nesta estrutura, maxicírculos e minicírculos, possuem mecanismos próprios de replicação e transcrição, distintos da replicação do DNA nuclear (Guilbride e Englund, 1998).

Outro mecanismo próprio é o processamento dos transcritos codificados pelo maxicírculo (maioria dos genes mitocondriais). Este processamento se dá por Editoração, em que se verifica a inserção ou a deleção de uridinas no transcrito primário. Este processo é determinado por RNA guias codificados pelos minicírculos (Stuart et al., 2005).

De modo geral, a organização da cromatina é similar ao observado nos demais eucariotos, contudo algumas diferenças podem ser ressaltadas. Um exemplo disto é o caso da cromatina que não se condensa em cromossomos visíveis durante a mitose e a membrana nuclear que permanece intacta durante este processo.

Não foram encontradas seqüências promotoras no DNA dos tripanossomatídeos. Os genes codificadores de proteínas carecem de íntrons e são transcritos policistronicamente (Lee e Van Der Ploeg, 1997). O RNA primário é processado em transcritos independentes por um processo de trans-splicing, onde a sequência do mini-exon de 39 nucleotídeos é adicionada à extremidade 5' de cada RNA mensageiro (Ullu e Tschudi, 1991).

Nos tripanossomas também não foram encontrados mecanismos de regulação transcricional, sendo toda a regulação da expressão gênica realizada por estabilização de mRNA (Teixeira, 1998; Mayer e Floeter-Winter, 2005).

Outros aspectos poderiam ser destacados por serem particulares dos tripanossomas, como a importação de tRNA, variação antigênica, entre outros que são de grande interesse bioquímico e evolutivo (McCulloch, 2004). Por tais características, entre outras, somadas à importância médica destes organismos, os estudos com tripanossomas são de grande relevância. 


\subsubsection{Trypanossoma cruzi}

O protozoário flagelado Trypanosoma cruzi é o agente etiológico da Doença de Chagas ou tripanossomíase americana que afeta de 16 a 18 milhões de pessoas no continente americano e coloca em risco de infecção outros 100 milhões (World Health Organization, 2002).

O T. cruzi é um parasita dixênico que tem insetos triatomíneos da família Reduviidae, subfamília Triatominae, comumente chamados de barbeiros, como hospedeiros intermediários, e mamíferos, como hospedeiros definitivos. Existem dois ciclos de transmissão vetorial do T.cruzi; o doméstico e o silvestre (Brener et al., 2000), mas a transmissão pode ocorrer também por transfusão sanguinea ou transplacentária.

Nos seres humanos a doença apresenta três fases: aguda, crônica e inderterminada ou latente. $\mathrm{Na}$ fase aguda, o indivíduo apresenta alta parasitemia e pode apresentar febre, mal estar e edemas. Na fase crônica ocorrem as principais manifestações cardíacas (cardiopatia) ou digestivas (esofagopatia e colopatia, principalmente), além do comprometimento de outros órgãos e dos transtornos no sistema nervoso (Minter et al., 1973; Brener et al., 2000). Na fase indeterminada ou latente a principal característica é ausência de sintomas. Embora já existam alguns medicamentos (Nifurtimox e Benznidazole) para tratamento desta doença, esses possuem princípios ativos muito fortes, sendo prejudiciais ao paciente. Além disso, a eficiência destas drogas é limitada e, na maior parte das vezes, não conseguem eliminar o parasita (Brener et al., 2000).

O parasita apresenta um ciclo de vida bastante complexo e foi recentemente revisto por De Souza (2002). Durante seu ciclo de vida, o parasita sofre alterações morfológicas, bioquímicas e estruturais, evolutivamente adaptadas aos diferentes microambientes encontrados durante a passagem em seus hospedeiros. Sem considerar as fases intermediárias, quatro formas distintas do protozoário são bem caracterizadas, as replicativas: epimastigota (forma flagelada, replicativa no intestino do inseto e não infectante), amastigota (forma com pequeno flagelo, intracelular, replicativa, presente nos mamíferos, provavelmente infectante). Formas não replicativas: tripomastigotas [forma flagelada, infectante, mas não replicativa, presente tanto no vetor (tripomastigotas metacíclicos), quanto nos hospedeiros mamíferos (formas tripomastigotas sanguíneas)]. 
Estas formas do ciclo de vida são nomeadas de acordo com a posição do cinetoplasto em relação ao núcleo e à região de emergência do flagelo (figura 2). O tripomastigota é a forma que representa o elo entre o vetor e os hospedeiros mamíferos (Brener, 1973; De Souza, 2002).
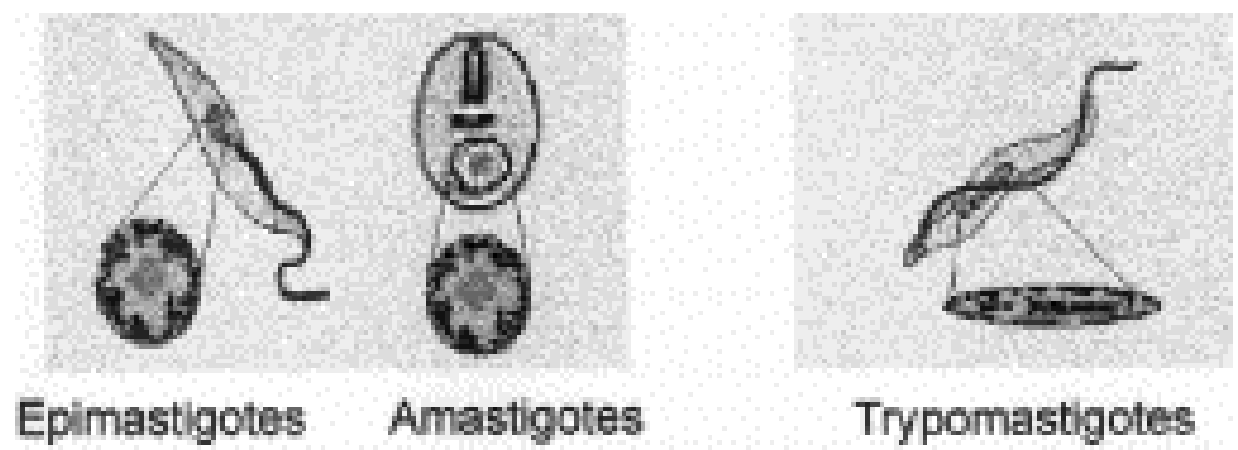

\section{Trypomastigotes}

Figura 2 - Formas do ciclo de vida do Trypanosoma cruzi, com ênfase na organização nuclear. FONTE: Elias et al.(2001).

O ciclo de vida do T. cruzi, que está representado na figura 3, ocorre da seguinte forma: quando o inseto vetor se alimenta com sangue do mamífero, defeca, e os tripomastigotas metacíclicos, eliminados nas fezes e urina, atravessam a pele ou mucosa do hospedeiro e penetram nas células próximas ao local da picada. Na célula, os tripomastigotas transformam-se em amastigotas que se multiplicam no citoplasma, e, após várias gerações, diferenciam-se em tripomastigotas que são liberados na corrente sanguínea para infectar células de vários tecidos como muscular, cardíaco ou nervoso.

Os insetos triatomíneos são contaminados com formas tripomastigotas sanguíneas ao se alimentar do sangue do mamífero infectado. No intestino médio do inseto, os tripomastigotas se diferenciam em formas epimastigotas e, no final do tubo digestivo, parte destas formas se diferencia em tripomastigotas metacíclicos, que são eliminados pelas fezes quando o inseto se alimenta novamente, começando assim um novo ciclo de infecção (De Souza, 2002). 


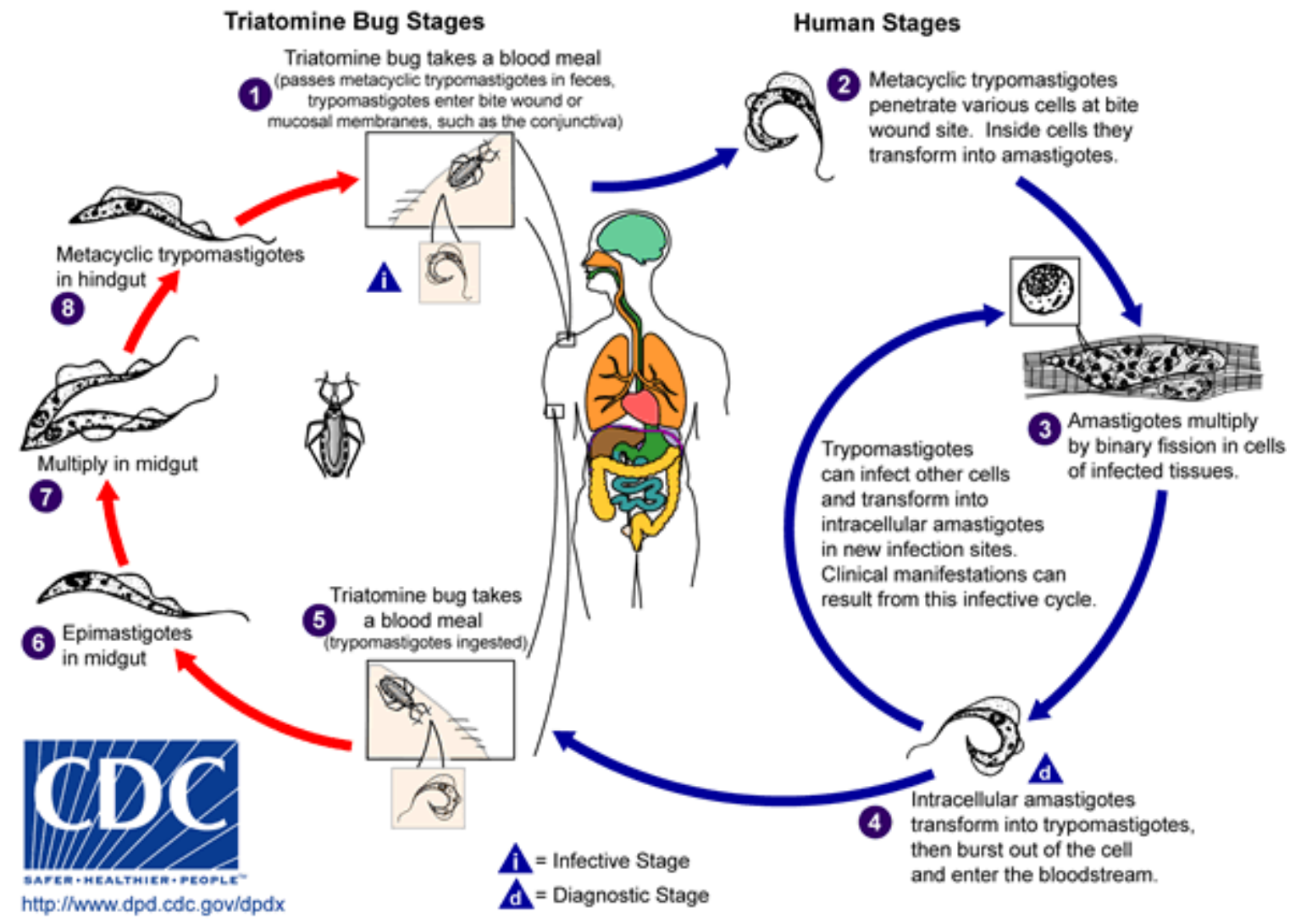

Figura 3- O ciclo de vida do Trypanosoma cruzi no inseto vetor e no hospedeiro humano. FONTE: Centro de Controle de Doenças (2010).

Como já mencionado anteriormente, diversos aspectos deste parasita têm sido amplamente estudados. Estes estudos são de fundamental importância a fim de entender a biologia destes organismos e auxiliar no caminho para o desenvolvimento de drogas para o combate da doença.

\subsubsection{Trypanosoma brucei}

O Trypanosoma brucei é o causador da Doença do Sono, sua distribuição é exclusivamente africana, devido ao fato da transmissão depender de insetos do gênero Glossina (tsé-tsé), que se encontram apenas na África (Matthews, 2005). Algumas espécies causam doenças em animais selvagens e domésticos (tripanossomíase africana animal), dentre elas 
Trypanosoma brucei brucei. Em humanos, a espécie Trypanosoma brucei é a causadora da tripanossomíase africana humana.

A doença do sono é um problema sério que atinge 36 países da África Subsaariana. No início do século XX, grandes áreas foram devastadas pela doença. Mais recentemente, segundo estimativas da Organização Mundial da Saúde (OMS), em 1986 aproximadamente 70 milhões de pessoas vivivam em áreas de risco; e em 1998 entre 300.000 e 500.000 pessoas estavam infectadas, mas apenas 40.000 casos haviam sido reportados. Atualmente, a OMS estima que 50.000 a 70.000 pessoas estejam infectadas (World Health Organization, 2010).

$\mathrm{O}$ ciclo de vida deste parasita será descrito a seguir e pode ser visualizado na figura 4 . O parasita se instala na saliva da tse-tsé, sendo injetado quando estas fazem seu repasto sanguíneo em humanos. O tripomastigota de T.brucei não invade as células (nem assume a forma de amastigota), alimentando-se e multiplicando-se enquanto tripomastigota nos fluidos corporais (incluindo sangue e fluido extracelular nos tecidos). A mosca é infectada quando se alimenta do indivíduo contaminado. Por cerca de um mês, o parasita assume várias formas (epimastigota principalmente) enquanto se multiplica no corpo da mosca, invadindo finalmente as glândulas salivares do inseto (Barret, 2003).

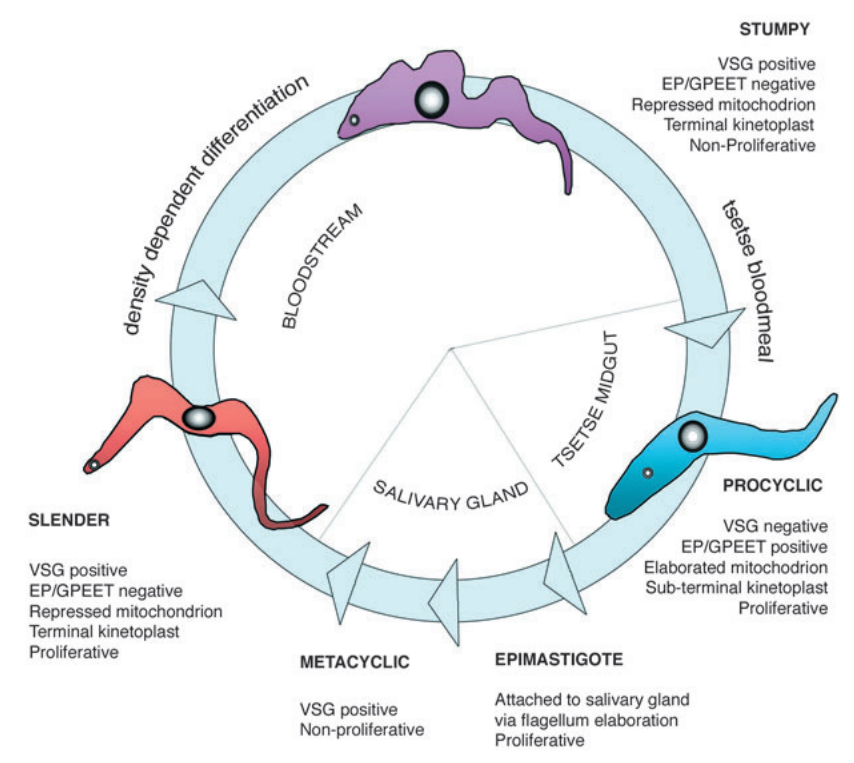

Figura 4- Ciclo de vida do Trypanosoma brucei. FONTE: Matthews (2005). 
Após a picada, o parasita multiplica-se localmente durante cerca de 3 dias, desenvolvendo um inchaço edematoso, denominado de cancro tripanossomico, que desaparece após três semanas, em média. Depois disto, os parasitas multiplicam-se no sangue, escapando do sistema imune do hospedeiro pelo processo de variação antigênica. Os sintomas iniciais cessam, mas os parasitas adaptados não são afetados pelos anticorpos produzidos e multiplicam-se gerando nova onda de parasitas e de sintomas. O resultado do processo de multiplicação, variação antigênica e seleção são ondas de sintomas agudos que vão aumentado até evoluírem para os sintomas crônicos (Barret, 2003). Mais tarde, o parasita invade o cérebro alterando o estado mental dos indivíduos infectados, desenvolvendo os distúrbios do sono, daí o nome da doença.

Assim como no Trypanosoma cruzi, muitos estudos têm sido feitos para a compreensão de diferentes aspectos da biologia destes organismos. Contudo, cabe lembrar para os dois casos, assim como também para a malária, leishmanioses, cólera, esquistossomose, entre outras, que os estudos para estas doenças, consideradas negligenciadas, poderiam ser mais efetivos. E com isso, os conhecimentos gerados poderiam fornecer as bases para o entendimento destes parasitas, das doenças por eles causadas, colaborando para o controle destas parasitoses tão importantes, principalmente nos países menos desenvolvidos.

\subsection{REPLICAÇÃO DO DNA}

Durante o processo evolutivo, linhagens celulares foram estabelecidas em três domínios: bactérias, archaeas e eucariotos (Woese e Fox, 1977). Estes grupos diferem em diversos aspectos, mas todos apresentam DNA dupla-fita e possuem a capacidade de replicar este material genético. O mecanismo básico de duplicação do material genético é bem conservado, entretanto a complexidade das proteínas envolvidas neste processo difere entre os diferentes organismos.

A complexidade das proteínas envolvidas no processo de replicação do DNA assegura que em cada divisão celular duas células filhas recebam uma perfeita cópia do material genético presente na célula mãe. Este evento pode ser compreendido em duas tarefas complexas: (a) o material genético deve ser duplicado sem erros, deleções ou duplicações. (b) Além disso, esta cópia deve ser perfeitamente segregada para as células filhas. A precisão e eficiência deste sistema são cruciais para a manutenção das espécies, e em organismos multicelulares não só são 
necessárias para a perpetuação das espécies, bem como também para evitar danos permanentes, como o câncer (Blow e Dutta, 2005).

De forma resumida, a duplicação ou a síntese de uma nova cadeia de DNA nas células, se faz a partir de uma fita simples de DNA molde e da regra de pareamento de bases complementares, de onde uma fita nova é gerada a partir do encadeamento dos nucleotídeos da fita molde. Os principais agentes envolvidos neste processo são enzimas especiais chamadas polimerases. Essas enzimas encarregam-se de adicionar um a um, os nucleotídeos à fita nova, bastando que haja na sua extremidade 3' um grupo hidroxil $(\mathrm{OH})$ livre, onde é ligado o próximo nucleotídeo pelo seu grupo fosfato.

O processo descrito de forma simplificada acima é organizado em múltiplos passos que compreendem as etapas de iniciação, elongamento e reparo. O processo de iniciação é caracterizado pela associação de uma série de proteínas ou complexos (maquinaria de préreplicação) a seqüências de DNA denominadas origens de replicação. Os eventos relacionados ao processo de iniciação têm dois objetivos principais: (a) o licenciamento das origens de replicação, que ocorre no final da mitose e início de G1 e (b) a ativação dos complexos de pré-replicação que ocorrem na fase $\mathrm{S}$ do ciclo celular (fase de síntese), resultando na abertura da dupla-fita de DNA permitindo sua duplicação, que efetivamente ocorre no processo de elongamento.

Após a abertura da dupla-fita de DNA, inicia-se a fase de elongamento. Como primeiro passo, a primase é recrutada para iniciar de fato a síntese da nova fita de DNA. Primeiramente ela sintetiza um primer de RNA e a partir deste começa a síntese da nova molecula de DNA. Após a preparação do DNA pela primase e outras proteínas acessórias, a DNA polimerase $\alpha$-primase é substituída por outras DNA polimerases. A DNA polimerase $\varepsilon$ e a DNA polimerase $\delta$ irão continuar a síntese da nova fita de DNA, sendo a primeira polimerase responsável pela síntese da fita contínua (leading strand), e a segunda pela síntese da fita descontínua (lagging strand). Nesta última etapa, há formação dos fragmentos de okazaki que devem ser unidos para formação de uma única molécula, para isso outra proteína inicia a degradação do primer de RNA. Em seguida, a DNA ligase irá promover a ligação entre os fragmentos de DNA (Garg e Burgers, 2005). 


\subsection{INICIAÇÃO: ORIGENS DE REPLICAÇÃO E O COMPLEXO DE PRÉ-REPLICAÇÃO}

\subsubsection{Origens de Replicação}

Para que ocorra o processo de iniciação, a célula conta com dois elementos genéticos: (i) uma regiao de DNA que funciona como origem de replicação e (ii) uma proteína, ou complexo protéico, capaz de reconhecer esta região como origem de replicação.

As origens de replicação são seqüências específicas de DNA, que podem variar em tamanho, em quantidade e seqüências entre os organismos (Boulikas, 1996). Apesar de muito distintas, as seqüências já descritas das origens de replicação apresentam regiões ricas em bases A e T, e pequenas seqüências invertidas que podem formar estruturas que são reconhecidas pelo complexo de pré-replicação (Grabowski e Kelman, 2003).

Como o genoma dos eucariotos é muito grande, para que este seja replicado em curto espaço de tempo sem perder a fidelidade da cópia, várias origens de replicação nos cromossomos são necessárias. Dentre os eucariotos apenas leveduras tem uma sequiência específica de DNA conhecida para a origem de replicação, que foi denominada de Autonomous Replicating Sequences - ARS.

Estas sequiências, ARS, são regiões não-codificantes de DNA com cerca de 100-200pb de comprimento. Esses sítios são acompanhados de uma seqüência curta, altamente conservada e essencial, denominada de elemento A ou ACS e motivos divergentes conhecidos como elementos B (Bell, 2002).

A origem de replicação em bactérias também já foi descrita. Estas apresentam uma única origem de replicação por cromossomo, denominada de oriC. Em Escherichia coli, oriC está localizada entre os genes gldA e mioC. A região de cerca de 250 pb contém múltiplas seqüências repetidas de 9pb denominadas de DNA Box (Fuller et al., 1984).

Outro grupo cujas origens estão sendo identificadas é Archaea, um grupo que partilha características de bactérias e eucariotos. Os cromossomos de organismos deste grupo lembram os de bactérias, sendo pequenos, circulares e com transcrição policistrônica. Contudo, a maquinaria de replicação e transcrição destes organismos está mais relacionada com eucariotos do que com bactérias (Kelman e Kelman, 2003). 
Em Archaea, seqüências responsáveis pela origem de replicação já estão descritas. Existe uma origem de replicação adjacente ao gene da proteína Orc1/Cdc6 em Pyrococcus abyssi (Myllikallio et al., 2000; Matsunaga et al., 2001). Outros gêneros de Archaea apresentam até três origens de replicação em um simples cromossomo, sendo duas origens associadas ao gene da proteína Orc1/Cdc6 (Lundgren et al., 2004; Robinson et al., 2004). A indicação de múltiplas origens de replicação aumenta a complexidade da coordenação da replicação.

As origens de replicação em Archaea contêm elementos repetitivos, denominados ORBS (Robinson et al., 2004), que funcionam como sítios de ligação da proteína Orc1/Cdc6. As ORBS diferem na seqüência de cada origem de replicação e esta diferença também define a afinidade de ligação a Orc1/Cdc6.

\subsubsection{O complexo de pré-replicação}

Conforme mencionado anteriormente nesta tese, a replicação do DNA em procariontes e eucariontes tem início com a formação de complexos de nucleoproteínas altamente organizadas nas origens de replicação (Bell, 2002; Stillman, 2005). Em eucariontes, este complexo é denominado complexo de pré-replicação (Newlon, 1997). Esta maquinaria é muito importante, pois seleciona no DNA as regiões onde a replicação irá começar e recruta, para estas regiões, as proteínas que de fato atuarão no processo de duplicação das fitas do DNA (Bell e Dutta, 2002).

Em eucariotos, esta maquinaria é formada por um complexo denominado ORC (complexo de reconhecimento da origem de replicação), formado por seis subunidades denominadas $\operatorname{Orc}_{1-6}$ (Bell e Stillman, 2002; Diffley, 2001). Este complexo reconhece as origens de replicação e possibilita então o recrutamento das outras proteínas do complexo (Bell e Dutta, 2002). Quando ORC interage com DNA, passa também a interagir com a proteína Cdc6 (cell division cycle), que juntamente com ORC recruta a proteína Cdt1. Finalmente, ORC, Cdc6 e Cdt1 recrutam o complexo MCM (complexo de manutenção do mini-cromossomo), formado por seis subunidades, $\mathrm{Mcm}_{2-7}$, que apresenta atividade de helicase, sendo fundamental para a duplicação do material genético (Figura 5, por Labib e Diffley, 2001). Após a formação deste complexo nas origens, estas se tornam licenciadas. A posterior ligação de fatores regulatórios e componentes da forquilha de replicação ao DNA vão permitir a abertura da dupla fita. A DNA polimerase é então recrutada e as forquilhas de replicação são efetivamente estabelecidas. 

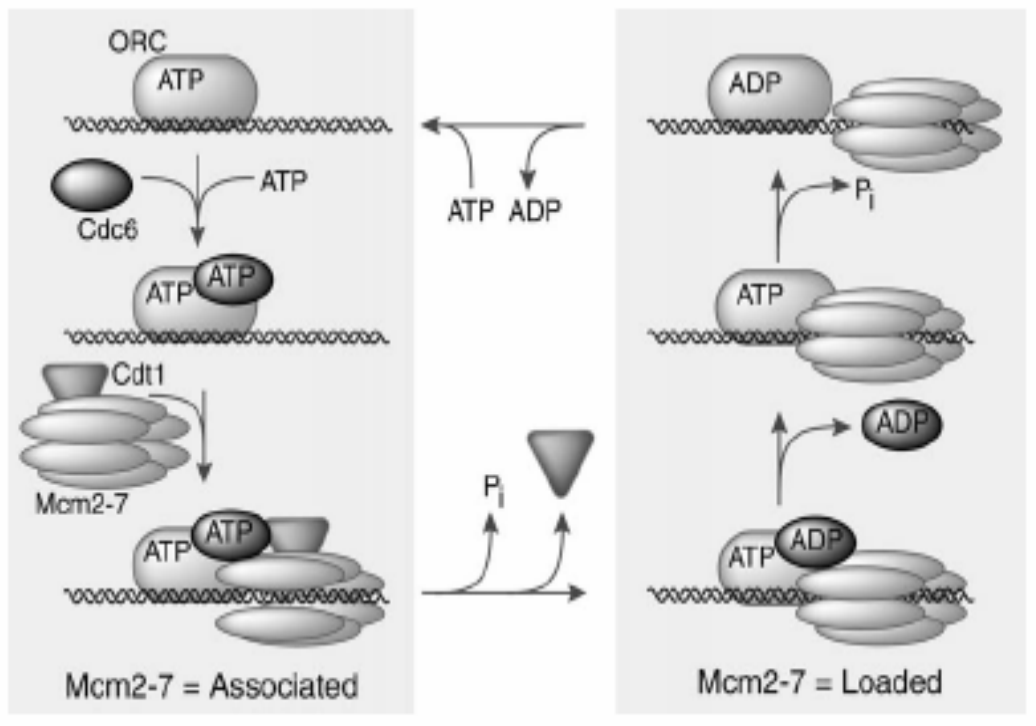

Figura 5 - Modelo de reconhecimento da origem de replicação e recrutamento do complexo de pré-replicação. FONTE: Labib e Diffley (2001). 


\subsection{ASPECTOS ESTRUTURAIS DOS COMPONENTES DA MAQUINARIA DE PRÉ- REPLICAÇÃO.}

\subsubsection{O complexo ORC e a proteína Cdc6}

O complexo ORC foi primeiramente purificado de extratos de S.cerevisiae que especificamente ligava um fragmento de DNA contendo as origens de replicação (Bell e Stillman, 1992). Em leveduras, ORC (413 KDa) é um heterohexâmero que consiste de seis proteínas nomeadas em ordem decrescente devido a suas massas relativas: Orc1 (120KDa), Orc2 (72KDa), Orc3 (62KDa), Orc4 (56KDa), Orc5 (53KDa) e Orc6 (50KDa).

Ortólogos de $\operatorname{Orc}_{1-5}$ foram identificados em organismos diversos (Duncker et al., 2009), sugerindo que estes genes existam em todos os eucariotos. Além dos ortólogos das subunidades de ORC, proteínas semelhantes a Orc1 têm sido amplamente descritas em espécies de eucariotos. A mais notável destas é a proteína Cdc6, que é também um componente da maquinaria de préreplicação. Orc1 é então mais relacionada com Cdc6 do que com qualquer outro componente do complexo ORC (Duncker et al., 2009).

Dentre as subunidades do complexo ORC, Orc1, Orc4 e Orc5 são classificadas como membros da família AAA+ (Neuwald et al., 1999). A família AAA+ corresponde a uma série de proteínas que apresentam atividade de ATPase e participam de várias atividades celulares (Neuwald et al., 1999). Este domínio AAA+ compreende os motivos Walker A e Walker B e as regiões denominadas sensor I e II. Estas regiões são características de proteínas que atuam como “Clamp-loaders”, proteínas que de maneira dependente de ATP formam um anel que envolve o DNA.

Os motivos Walker A e B e as regiões sensor I e II são os responsáveis pela ligação e hidrólise de ATP (Neuwald et al., 1999). A ligação e a hidrólise do ATP resultam na mudança conformacional do complexo, facilitando o recrutamento seriado que existe durante o agrupamento do complexo de pré-replicação nas origens (Erzberger e Berger, 2006).

Além do domínio AAA+, Orcs, com exceção de Orc6, apresentam 1 ou 2 domínios de ligação ao DNA (“domínio WH - winged helix”) (Duncker et al., 2009; Chen et al., 2007). As proteínas Orc2 e Orc4 também apresentam outras regiões que interagem com o DNA, como as regiões que ligam seqüências ricas em AT (Duncker et al., 2009). 
A proteína Cdc6 (58 $\mathrm{KDa}$ em $S$. cerevisiae) foi originalmente isolada em mutantes termosensíveis de Cdc em S.cerevisiae e foi classificada como sendo participante do início da replicação (Hartwell, 1976). Cdc6 está muito relacionada com a proteína Orc1 e apresenta o domínio AAA+, com os motivos Walker A e Walker B e as regiões sensor I e II (Duncker et al., 2009). Assim como Orc1, Cdc6 apresenta uma intrínseca atividade de ATPase in vitro (Speck e Stillman, 2007).

Na figura 6 é possível encontrar o esquema estrutural das proteínas do complexo ORC e da proteína Cdc6.

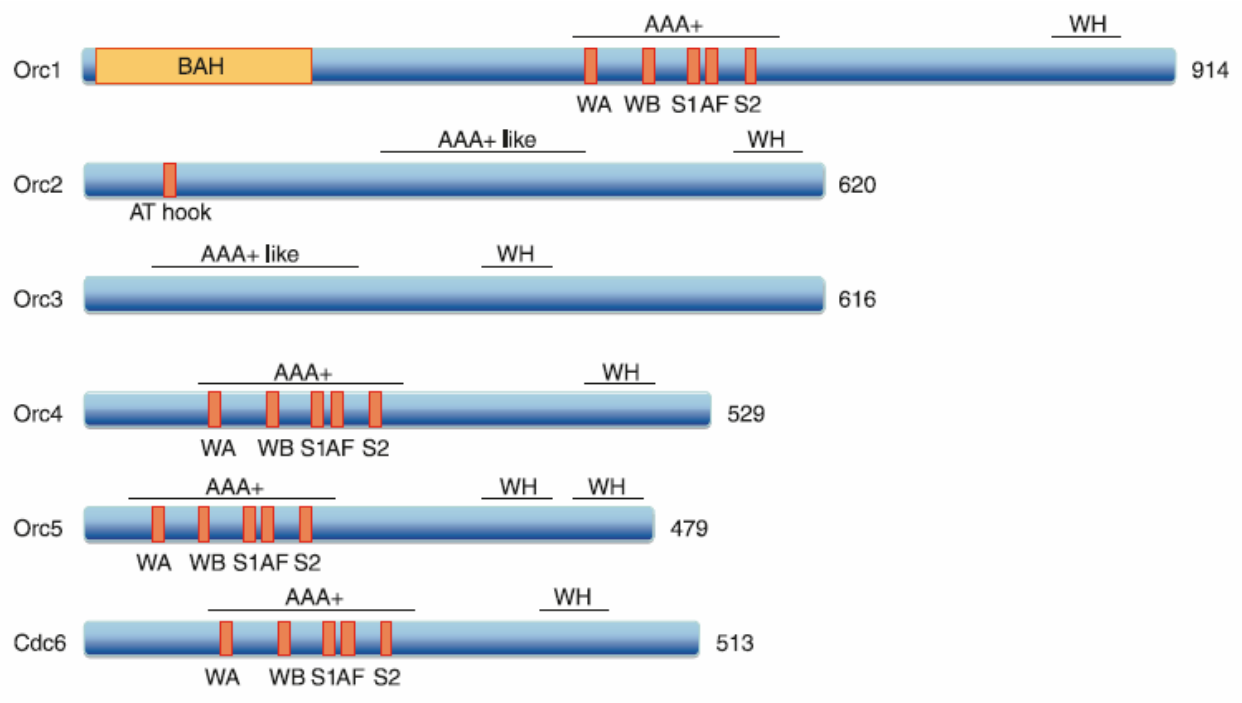

Figura 6- Esquema estrutural das proteínas do complexo ORC e da proteína Cdc6 de S. cerevisiae. Os totais de aminoácidos são descritos ao término de cada estrutura. Os domínios BAH (Domínio exclusivo de Orc1 que interage com a proteína Sir, envolvida em silenciamento em S.cerevisiae), AAA+ e WH estão demonstrados na figura.

FONTE: Kawakami e Katayama (2010). 


\subsubsection{CDT1}

A função principal da proteína Cdt1 é recrutar o complexo $\mathrm{MCM}$ para as origens (Nishitani et al., 2000). A estrutura de Cdt1 pode ser divida em três partes: uma região variável no N-terminal que liga DNA, uma região mediana que liga a proteína geminina, sua principal moduladora em metazoários (Lee et al., 2004). E outra região no C-terminal que liga o complexo MCM e parece ser essencial para o licenciamento das origens (Lee et al., 2004).

Esta região no C-terminal da proteína apresenta o domínio WH (winged helix) que para as outras proteínas do complexo serve para a associação com o DNA, no caso da proteína Cdt1 este domínio parece estar relacionado com a interação da proteína com o complexo MCM (Khayrutdinov et al., 2009).

\subsubsection{O Complexo MCM}

O recrutamento do complexo MCM para as origens parece ser o objetivo da formação do complexo de pré-replicação (Costa e Onesti, 2009). O complexo MCM é formado por seis subunidades e foi originalmente descoberto e nomeado como fator que suporta a manutenção do minicromosomo em leveduras (Forsburg, 2004).

Todos os genomas de eucariotos possuem pelo menos seis parálogos do complexo MCM $\left(\mathrm{Mcm}_{2-7}\right)($ Costa e Onesti, 2009). Estas proteínas apresentam uma conservação estrutural que permite dividi-las em três domínios (Costa e Onesti, 2009). A região N-terminal mostra um baixo grau de conservação, já o "core", que é a região central apresenta o domínio AAA+, que é responsável pela região catalítica. Na região C-terminal das proteínas do complexo MCM é possível encontrar nos eucariotos uma região hidrofóbica, que é compatível com o domínio WH encontrado na região C-terminal das proteínas MCM, encontradas em Archaea (Aravind e Koonin, 1999).

Apesar de individualmente cada subunidade apresentar estes domínios indispensáveis para a atividade do complexo, estudos têm demonstrado a função coordenada das subunidades na estrutura do complexo (Bell e Dutta, 2002). Mutações em cada um dos putativos locais de ligação de ATP em todas as subunidades do complexo reduzem drasticamente a atividade, indicando que esta atividade é coordenada pelas seis subunidades do complexo (Bell e Dutta, 2002). 
De forma mais detalhada em leveduras, o complexo MCM intacto apresenta uma robusta atividade de ATPase. A formação de um sub-complexo MCM 4,6,7 apresenta baixa atividade de ATPase. Já o sub-complexo MCM 2,3,5 isolado não apresenta atividade de ATPase. Entretanto, quando ocorre a adição destes sub-complexos de modo a restaurar o completo nativo $\left(\mathrm{Mcm}_{2-7}\right)$, a atividade de ATPase também é restaurada (Bell e Dutta, 2002).

Quanto à atividade de helicase predita para este complexo, estudos têm sido feitos de modo a demonstrar estas atividades em diferentes organismos, entretanto muito pouco se sabe. Um análogo da proteína de eucariotos em Archaea, Methanobacterium thermoautorophicum apresenta uma robusta atividade de helicase (Chong et al., 2000). Já em camundongos, assim como em $S$. pombe somente o sub-complexo MCM 4,6,7 isolado apresenta atividade de helicase (Bell e Dutta, 2002).

\subsection{O RECRUTAMENTO DA MAQUINARIA DE PRÉ-REPLICAÇÃO EM DIFERENTES ORGANISMOS}

\subsubsection{Leveduras}

O primeiro passo no processo de início da replicação é a ligação de ORC às origens de replicação. A ligação de ORC e outros fatores modula a estrutura da cromatina de tal forma que esta consegue se tornar apta para a continuidade da replicação (Lipford e Bell, 2001).

O complexo ORC possui a capacidade de ligar-se a DNA dupla-fita ou DNA simples-fita, mas exibe diferentes propriedades nestas diferentes condições. Nesta primeira etapa, estudos demonstraram a requisição de ATP para o reconhecimento da origem por ORC (Lei e Tye, 2009). A ligação de ORC à dupla-fita é específica e inibe a atividade de ATPase deste complexo. Ao contrário disto, a ligação de ORC à seqüência não específica simples-fita estimula sua atividade de ATPase (Lei e Tye, 2009). Análises de microscopia eletrônica mostram que ORC alterna sua conformação quando ligada a dupla-fita ou simples-fita de DNA (Lee et al., 2000). Resumindo então o mecanismo, a alta atividade de ATPase de ORC faz com que esta não tenha uma interação estável com DNA. Diante da sequiência específica da origem de replicação, ORC inibe sua atividade de ATPase, muda sua conformação e passa a interagir com Cdc6 (Lei e Tye, 2009). 
A interação e a estabilidade da ligação ORC-Cdc6-DNA também é regulada, neste caso, pela atividade de ATPase de Cdc6, que é alta na presença de DNA inespecífico, desestabilizando o complexo (Speck e Stillman, 2007). Assim, tanto a atividade de ATPase de ORC quanto de Cdc6 atuam na seleção de origens específicas de replicação. Em um segundo momento, a formação do complexo ORC-Cdc6-DNA permite tal configuração que a proteína Orc6 presente no complexo ORC passa a interagir com a proteína Cdt1 (Chen et al., 2007).

ORC, Cdc6 e Cdt1 são agora capazes de interagir com o complexo MCM. Nesta etapa, a baixa hidrólise de ATP por Cdc6 que servia para estabilizar a interação ORC-Cdc6- DNA, é também requerida para o carreamento do complexo MCM para as origens (Evrin et al., 2009). Após o carreamento do complexo MCM para as origens, a hidrólise de ATP por Orc1 possibilita ao complexo MCM interagir diretamente com o DNA (Randell et al., 2006).

A maneira como o complexo MCM se associa com as origens de replicação ainda não está muito clara. Com base na similaridade da proteína Cdc6 com a proteína "Clamp-Loader" PCNA (Koonin, 1993), acredita-se que Cdc6 facilite topologicamente a ligação do complexo MCM com o DNA, capacitando MCM a envolver o DNA como um anel hexamérico (Lee e Bell, 2000).

Embora a presença destas proteínas (ORC, Cdc6 e Cdt1) sejam pré-requisitos para a presença do complexo MCM nas origens, na etapa final, que precede a ativação da origem, não é necessária a manutenção destas proteínas. Neste ponto, a dissociação destas, ORC, Cdc6 e Cdt1 das origens também requer a hidrólise de ATP (Tsakraklides e Bell, 2010).

O que deve ser ressaltado a respeito do processo acima descrito é que tanto o domínio $\mathrm{AAA}+$ (relacionado à participação do ATP), quanto o domínio WH (interação com o DNA) de ORC, Cdc6 e MCM têm participação ativa em todo o processo. Entretanto, não estão muito definidas ainda as contribuições de cada domínio para o papel funcional da maquinaria de préreplicação (Tsakraklides e Bell, 2010).

\subsubsection{Metazoários}

Em metazoários, um dos primeiros eventos que ocorre, similar aos outros organismos, no que diz respeito à replicação do DNA, é a ligação do complexo ORC, composto por Orc1-Orc6, ao DNA, que recruta seguidamente as proteínas Cdc6 e Cdt1. O carreamento do complexo MCM 
às origens provavelmente envolve a abertura do anel do complexo MCM de modo a envolver o DNA.

Assim como em leveduras, as proteínas do complexo ORC, Cdc6 e Cdt1 são necessárias somente para o carreamento do complexo MCM às origens. Depois disto, uma vez o complexo MCM associado às origens, estas proteínas não são necessárias, sendo reguladas de modo a não ativarem novas origens (Donovan et al., 1997; Rowles et al., 1999).

Em metazoários, assim como em leveduras, cerca de 14 proteínas que participam do complexo de pré-replicação, isto incui todas as proteínas dos complexos ORC e MCM, apresentam motivos consenso para a ligação de nucleotídeos. A ligação e hidrólise de nucleotídeos, que deve prover energia necessária para acomodação do complexo nas origens, têm se mostrado indispensáveis não só em metazoários como em todos os outros organismos (Blow e Dutta, 2005).

A proteína Cdt1 não apresenta atividade de ATPase, entretanto o papel de "clamp loader" das proteínas da maquinaria só é alcançado quando Cdc6 já encontra-se junto à ORC e quando Cdt1 carreia o complexo MCM. Somente nos metazoários, um importante inibidor de Cdt1 é encontrado, a proteína Geminina que se liga diretamente à proteína Cdt1 e impede a interação desta com o complexo MCM (Tada et al., 2001).

\subsubsection{Archaea}

Archaea são organismos unicelulares, que, embora procariotos, possuem muita semelhança em relação à maquinaria de replicação, transcrição, tradução, recombinação e reparo de eucariotos (Lundgren e Bernander, 2005). Nesta linhagem evolutiva o número de origens de replicação varia entre as espécies, podendo haver apenas uma origem ou várias (Robinson e Bell, 2005).

Em Archaea não existem 6 polipeptídeos diferentes de Orc para formar o complexo Orc 1-6. Ao contrário, estes organismos expressam uma única proteína similar tanto a Orc1 quanto a Cdc6 (De FM et al., 2003, 2004a, 2004b, 2006; Pucci et al., 2007). O papel funcional desta proteína denominada de Orc1/Cdc6 já foi demonstrado, uma vez que ela associa-se ao DNA em sequências específicas, apresenta atividade de ATPase e interage com o complexo MCM (Grainge et al., 2003). 
As estruturas tridimensionais de Orc1/Cdc6 de duas espécies de Archaeas demonstraram a presença dos domínios $\mathrm{AAA}^{+}$ATPase e winged helix (WH), que são conservados em Orc1 e Cdc6 (Singleton et al., 2004).

Diferente dos eucariotos, a maioria dos representantes de Archaea expressa apenas um polipeptídio de MCM que forma um homomultímero (Chong et al., 2000; Kelman et al., 1999; Schechter et al., 2000). Até o ano de 2007, nenhuma proteína havia sido encontrada com similaridade a proteína Cdt1 nestes organismos. Robinson e Bell (2007) demonstraram a presença de uma proteína, denominada WHIP (winged-helix initiator protein), que pode ter a função de Cdt1 nestes organismos (dados ainda não demonstrados na literatura).

\subsection{CONTROLE DA RE-REPLICAÇÃO SOBRE OS COMPONENTES DA MAQUINARIA DE PRÉ-REPLICAÇÃO}

A ligação do complexo de pré-replicação às origens de replicação (licenciamento das origens) ocorre na fase G1 do ciclo celular. Para garantir que esta interação não ocorra fora do período de licenciamento em G1, e assim garantir uma única replicação do DNA em cada ciclo celular, é importante que a capacidade de licenciar novas origens de replicação seja bloqueada antes de entrar na fase $\mathrm{S}$ do ciclo celular. Como ORC, Cdc6 e Cdt1 são requeridas para carrear o complexo MCM, mas não são requeridas para a contínua associação do mesmo, controlar a atividade destas proteínas durante o ciclo celular é uma forma de prevenir a re-replicação.

Estudos em leveduras têm indicado que a atividade de kinases dependentes de ciclinas (CDKs) nas fases G2 e S são necessárias para controlar a re-replicação. Baixos níveis de CDK no início do ciclo celular (G1) permitem o licenciamento das origens e altos níveis de CDK no fim da fase G1 leva a inibição de novos licenciamentos (Diffley, 1996).

Em leveduras, a função de CDK parece redundante para prevenir a re-replicação, porque além do controle que existe em função dos níveis de CDK acima descritos, que vão ter atuação em certas proteínas, as CDKs também apresentam como alvos as proteínas da maquinaria de préreplicação. Um dos principais substratos da regulação de CDK é a proteína Cdc6, que é alvo para degradação seguida de fosforilação por CDK na transição G1-S. A expressão da proteína Cdc6 também é regulada, alcançando concentração máxima na transição M-G1 (Blow e Dutta, 2005). 
Em relação ao complexo ORC, este parece sofrer ação de CDKs também, via fosforilação. Em leveduras as CDKs são diretamente recrutadas às origens, onde o complexo ORC se encontra. Lá elas atuam sobre o complexo ORC de modo a mantê-lo em um estado inativo durante as fases S e G2 (Nguyen et al., 2001; Vas et al., 2001; Wuarin et al., 2002).

Em relação à proteína Cdt1, os níveis desta proteína no final da mitose e início de G1 também são controlados via CDKs, da mesma forma como com as proteínas Cdc6. Além disso, parece haver exportação das proteínas Cdt1 e MCM durante as fases S, G2 e mitose (Labib et al., 1999).

Em metazoários existem evidências do papel das CDKs sobre o controle da re-replicação, contudo, o papel das CDKs em inibir o licenciamento das origens é menos claro do que em leveduras (Blow e Dutta, 2005). O complexo ORC de mamíferos é um complexo muito lábil. A proteína Orc 1 é marcada para degradação no início da fase $S$ ou em sua progressão, via atividade das proteínas CDKs.

A proteína Cdc6 destes organismos parece ficar ligada ao DNA durante todo o ciclo, entretanto, quando os níveis de Cdc6 estão mais altos, esta é exportada do núcleo na fase S.

O grande controle em metazoários está sobre regulação da proteína Cdt1, via degradação no final de G1 e no início da fase S por um processo que depende da atividade de uma classe de ubiquitina-ligases (Nishitani et al., 2001; Li et al., 2003).

Em particular, nestes organismos, a proteína Cdt1 é inibida por uma proteína denominada Geminina. A interação de Cdt1 com a proteína Geminina nas fases G2 e M estabilizam a proteína de modo que esta fica protegida da degradação mediada por ubiquitinas.

A atividade da proteína Geminina também está sob regulação, no final da mitose, por proteólise ou por inativação via CDKs, que a impede de ligar-se a Cdt1, permitindo assim a formação do complexo de pré-replicação no início de G1 (Blow e Dutta, 2005).

$\mathrm{Na}$ figura 7, pode-se ver um resumo das diferentes formas de controle sofrido pelos componentes da maquinaria de pré-replicação em leveduras e metazoários. 
A yeast

\begin{tabular}{|ccc|}
\hline ORC inhibited $/$ & ORC & ORC inhibited \\
\hline Cdc6 degraded $/$ & Cdc6 & Cdc6 degraded \\
\hline Cdt1 exported $/$ & $\mathrm{Cdt1}$ & Cdt1 exported \\
\hline Mcm2-7 exported $/$ & $\mathrm{Mcm} 2-7$ & Mcm2-7 exported \\
\hline
\end{tabular}

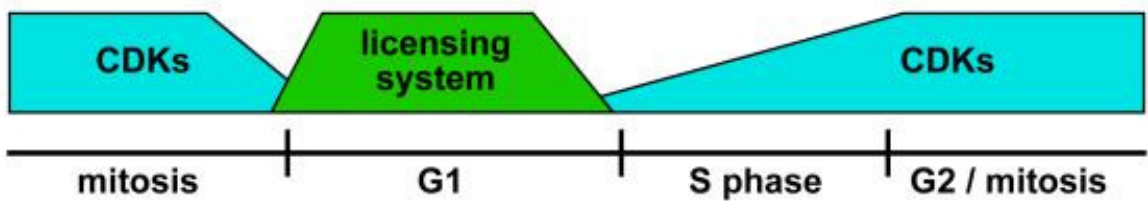

\section{B metazoans}

\begin{tabular}{|l|c|}
\hline ORC inhibited $/$ ORC & Orc1 ubiquitinated and degraded? \\
\hline Cdc6 inhibited $/$ Cdc6 exported? \\
\hline Cdt1 : geminin $/$ Cdt1 \\
\hline
\end{tabular}

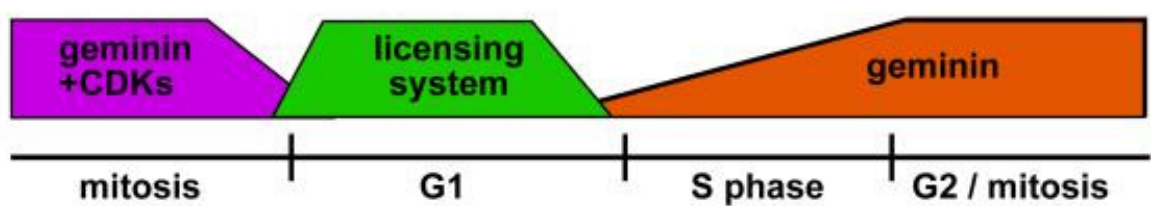

Figura 7 - Regulação no ciclo celular dos componentes do complexo de pré-replicação em leveduras e metazoários.

FONTE: Blow e Dutta (2005). 


\section{CONSIDERAÇÕES FINAIS}

A presença de uma única proteína agindo como Orc1 e Cdc6 coloca os tripanosomas muito próximos a eubactérias e Archaea, que possuem uma única proteína para reconhecer as origens de replicação no DNA e agrupar toda a maquinaria de pré-replicação antes do início da replicação (figura 43).

Tem sido especulado que eucariotos tenham seis proteínas essenciais (complexo ORC) para realizar a função de reconhecer a origem de replicação, porque a regulação temporal do início da replicação do DNA através da fase $\mathrm{S}$ deve requerer mais coordenação dentro da progressão do ciclo celular do que em bactérias e Archaea (Stillman, 2005). Contudo, os resultados obtidos nestes estudos mostram que os tripanossomas, que são eucariotos e devem dispor de mecanismos para controlar a replicação e garantir a correta segregação dos cromossomos, contém somente uma proteína para recrutar a maquinaria de pré-replicação.

(A)

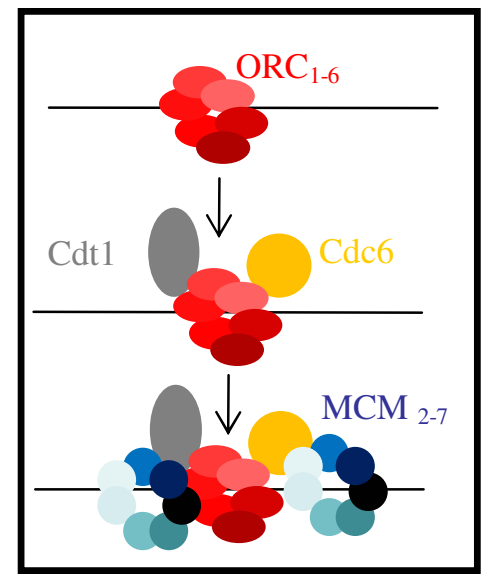

Leveduras e metazoários
(B)

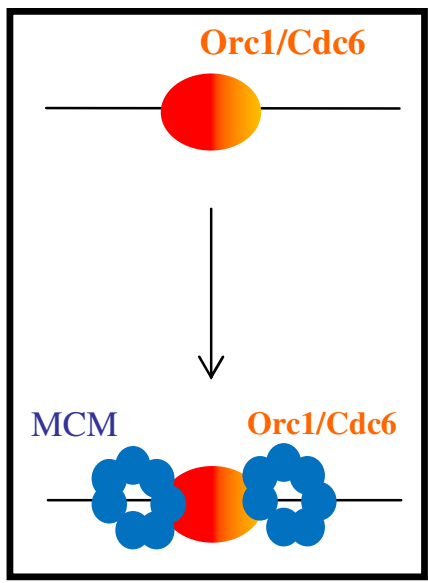

Archaea
(C)

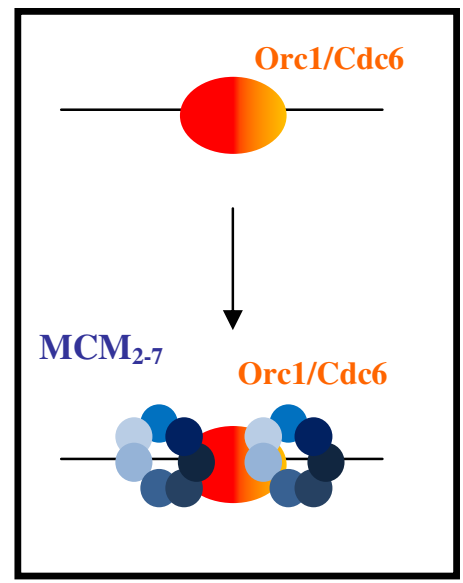

Tripanossomas

Figura 43- Complexidade da maquinaria de pré-replicação. Leveduras e metazoários (A), Archaea (B) e Tripanossomas (C). 
Perspectivas futuras colocam os tripanossomas como ótimos modelos para entender à transição de uma célula com um cromossomo, sem núcleo individualizado, com uma proteína para dar início a todo processo de replicação para organismos contendo uma célula com muitos cromossomos, um núcleo individualizado e um complexo de multiproteínas para dar início à replicação. 


\section{REFERÊNCIAS*}

Abuin G, Freitas-Junior LH, Colli W, Alves MJ, Schenkman S. Expression of trans-sialidase and $85-\mathrm{KDa}$ glycoprotein gene in T.cruzi is differentially regulated at the post-transcriptional level by labile protein factors. J Biol Chem. 1999;274(19):13041-7.

Aravind L, Koonin EV. DNA-binding proteins and evolution of transcription regulation in the archaea. Nucleic Acids Res. 1999;27:4658-4670.

Armougom FS, Moretti O, Poirot S, Audic P, Dumas B, Schaeli V, Keduas, C Notredame. Expresso: automatic incorporation of structural information in multiple sequence alignments using 3D-Coffee. Nucleic Acids Res. 2006; 34:W604-W608.

Bangs JD, Uyetake L, Brickman MJ, Balber AE, Boothroyd JC. Molecular cloning and cellular localization of BiP homologue in Trypanosoma brucei. Divergent ER retention signals in a lower eukaryote. J Cell Sci. 1993;105:1101-1113.

Barret MP. The Trypanosomiase. The Lancet, Glasgow. 2003;362(9394):1469-1480.

Bell SP, Stillman B. ATP-dependent recognition of eukaryotic origins of DNA replication by a multiprotein complex. Nature. 1992;357:128-34.

Bell SP, Mitchell J, Leber J, Kobayashi R, Stillman B. The multidomain structure of Orc1p reveals similarity to regulators of DNA replication and transcriptional silencing. Cell. 1995;83:563-568.

Bell SP. The origin recognition complex: from simple origins to complex functions. Genes Deve. 2002;16(6): 659-672.

Bell SP, Dutta A. DNA replication in eukaryotic cells. Annu Rev Biochem. 2002;71:333-374.

Bell SP, Stillman B . ATP-dependent recognition of eukaryotic origins of DNA replication by a multiprotein complex. Nature. 2002;357:128-34.

Bioinformatics Group, UCL Departament of Computer Science [PSI-Pred]. Available from: http://bioinf.cs.ucl.ac.uk/psipred [cited 2009 Jul 20].

* De acordo com: International Committee of Medical Journal Editors. Uniform requirements for manuscripts submitted to Biomedical Journal: sample references. Available from: http://www.icmje.org [cited 2007 May 22]. 
Blow JJ, Dutta A. Preventing re-replication of chromossomal DNA. Nat Rev Mol Cell Biol. 2005 June;6(6):476-486.

Boulikas T. Common structural features of replication origins in all life forms. J Cell Biochem. 1996 Mar;60(3):297-316.

Brener Z. Biology of Trypanosoma cruzi. Annu Rev Microbiol. 1973;(27):347-382.

Brener Z, Andrade ZA, Barral-Neto M. Trypanosoma cruzi e Doença de Chagas. 2. ed. Local: Ed. Guanabara Koogan; 2000.

Brun R, Schönenberger M. Cultivation and in vitro cloning of procyclic culture forms of Trypanosoma brucei in a semi-defined medium. Acta Trop. 1979; 36:289-292.

Camargo EP. Growth and differentiation in $T$. cruzi : Origin of metacyclic trypomastigotes in liquid media. Rev Inst Med Trop. 1964;6:93-100.

Centro de Controle de Doenças (CDC). Ciclo de vida do T.cruzi. Available from: http://www.dpd.cdc.gov [cited 2010 Mar 10].

Chen Z, Speck C, Wendel P, Tang C, Stillman B, Li H. The architecture of the DNA replication origin recognition complex in Saccharomyces cerevisiae. Proc Natl Acad Sci USA. 2000 Jul 29;105(30):10326-31.

Chen S, Vries MA, Bell SP. Orc6 is required for dynamic recruitment of Cdt1 during repeated Mcm 2-7 loading. Genes Deve. 2007; 21(22):2897-2907.

Chong JPJ, Hayashi MK, Simon MN, Xu RM , Stillman B. A double-hexamer archaeal minichromosome maintenance proteins is an ATP-dependent DNA helicase. Proc Natl Acad Sci USA. 2000; 97:1530-1535.

Costa A, Onesti S. Structural biology of MCM helicases. Crit Rev Biochem Mol Biol. 2009; 44950:326-342.

Da Cunha JP, Nakayasu ES, de Almeida IC, Schenkman S . Post-translational modifications of Tripanosoma cruzi histone H4. Mol Biochem Parasitol. 2006;150: 268-277.

De FM, Esposito L, Pucci B, Carpentieri F, De FM, Rossi M, et al. Biochemical characterization of a CDC6-like protein from the crenarchaeon Sulfolobus solfataricus. J Biol Chem. 2003 Nov 21;278(47):46424-31.

De FM, Esposito L, Pucci B, De FM, Rossi M, Pisani FM . A CDC6-like factor from the archaea Sulfolobus solfataricus promotes binding of the mini-chromosome maintenance complex to DNA. J Biol Chem. 2004 Oct 8;279(41):43008-12. 
De FM, Esposito L, Pucci B, De FM, Manco G, Rossi M, et al . Modular organization of a Cdc6-like protein from the crenarchaeon Sulfolobus solfataricus. Biochem J. 2004 Aug 1;381(Pt 3):645-53.

De FM, Esposito L, Rossi M, Pisani FM. Biochemical characterization of two Cdc6/ORC1like proteins from the crenarchaeon Sulfolobus solfataricus. Extremophiles. 2006 Feb;10(1):61-70.

De Souza W . Basic Cell Biology of T.cruzi. Curr Pharm Des. 2002;8(4):269-285.

Diffley JF . DNA replication: building the perfect switch. Curr Biol. 2001;11:367-70.

Diffley JF . Once and only once upon a time: specifying and regulating origins of DNA replication in eukaryotic cells. Genes Dev. 1996;10:2819-2830.

Donovan S, Harwood J, Drury LS, Diffley JF . Cdc6 dependent loading of Mcm proteins onto prereplicative chromatin in budding yeast. Proc Natl Acad Sci USA. 1997;94:5611-5616.

Duncker BP, Chesnokov LN, McConkey BJ . The origin recognition complex protein family. Genome Biol. 2009;10(3):214.

Elias MCQB, Marques Porto R, Freymuller E, Schenkman S . Transcription rate modulation through the Trypanosoma cruzi life cycle occurs in parallel with changes in nuclear organization. Mol Biochem Parasitol. 2001;112:79-90.

Elias MC, Faria M, Mortara RA, Motta MCM, Souza W, Thiry M, Schenkman S . Chromosome Localization Changes in the T.cruzi nucleus. Eukaryot Cell. 2002;1(6):944-953.

Elias MC, Cunha JPC, Faria FP, Mortara RA, Freymuller E, Schenkman S. Morphological events during the T. cruzi cell cycle. Protist. 2007;158:147-157.

Erzberger JP, Berger JM . Evolutionary relationships and structural mechanisms of AAA+ proteins. Annu Rev Biophys Biomol Struct. 2006;35(1):93-114.

European Bioinformatics Institute - EBI [Tcoffee]. Available from: http://www.ebi.ac.uk/Tcoffee [cited 2009 Jul 15]

Evrin C, Clarke P, Zech J, Lurz R, Sun J, Uhle S, Li h, Stillman B, Speck C. A doublehexameric MCM2-7 complex is loaded onto origin DNA during licensing of eukaryotic DNA replication. PNAS. 2009;106(48):20240-20245.

Fiske CH, Subbarow Y . The colorimetric determination of phosphorus. J Biol Chem. 1925; 66:375-400.

Forsburg SL. Eukaryotic MCM proteins: Beyond replication initiation. Microbiol Mol Biol ver. 2004;68:109-131. 
Fundação Oswaldo Cruz -FIOCRUZ. Esquema do T.cruzi. Available from: http://www.fiocruz.br [cited 2010 Feb 20].

Fuller RS, Funnel BE, Kornberg A . The dnaA protein complex with the E. coli chromosomal replication origin (oriC) and other DNA sites. Cell. 1984;38(3):889-900.

Gajiwala KS, Burley SK. Winged helix proteins. Curr Opin Struct Biol. 2000;10:110-116.

Garg P, Burgers PM. DNA polymerases that propagate the eukaryotic DNA replication fork. Crit Rev Biochem Mol Biol. 2005;40(2):115-28.

Genome Net Database Resources, Kyoto. University Bioinformatics Center. DBGET [Database]. Available from: http://www. genome.ad.jp/dbget/ [cited 2006 Mar 08].

Gietz DR, Schiestl RH . High efficiency yeast transformation using the LiAc-ss carrier DNAPEG method. Nature Protocols. 2007;2(1):31-34.

Gibson DG, Bell SP, Aparicio OM . Cell cycle execution point analysis of ORC function and characterization of the checkpoint response to ORC inactivation in Saccharomyces cerevisiae. Genes Cells. 2006;11:557-573.

Grabowski B, Kelman Z . Archeal DNA replication: eukaryal proteins in a bacterial context. Annu Rev Microbiol. 2003;57:487-516.

Grainge I, Scaife S, Wigley DB. Biochemical analysis of components of the pre-replication complex of Archaeoglobus fulgidus. Nucleic Acid Res. 2003;31:4888-4898.

Guenther B, Onrust R, Sali A, O'Donnell M, Kuriyan J . Crystal structure of the delta' subunit of the clamp-loader complex of E. coli DNA polymerase III. Cell. 1997 Oct 31;91(3):335-45.

Guilbride DL, Englund PT . The replication mechanism of kinetoplast DNA networks in several trypanosomatid species. J Cell Sci. 1998;111:675-679.

Hartwell LH, Mortimer RK, Culotti J, Culotti M . Genetic Control of the Cell Division Cycle in Yeast: V. Genetic Analysis of cdc Mutants. Genetics. 1973 Jun;74(2):267-86.

Jones D $\mathrm{T}$. Protein secondary structure prediction based on position-specific scoring matrices. J Mol Biol. 1999;292:195-202.

Khayrutdinov BI, Bae WJ, Yun YM, Lee JH, Tsuyama T, Kim JJ, Hwang E, Ryu KS, Cheong HK, Cheong C, Ko JS, Enomoto T, Karplus PA, Guntert P, Tada S, Jeon YH, Cho Y. Structure of the Cdt1 C-terminal domain: Conservation of the winged helix fold in replication licensing factors. Protein Science. 2009;18:2252-2264.

Kawakami H, Katayama T. DnaA, ORC and Cdc6: similarity beyond the domains of life and diversity. Biochem. Cell Biol. 2010;88:49-62. 
Kelman Z, Lee J.K., Hurwitz J. The single minichromosome maintenance protein of Methanobacterium thermoautotrophicum delta H contains DNA helicase activity. Proc Natl Acad Sci USA. 1999;96:14783-14788.

Kelman LM, Kelman Z . Archaea: an archetype for replication initiation studies? Mol Microbiol. 2003 May;48(3):605-15.

Koonin EV. A common set of conserved motifs in a vast variety of putative nucleic aciddependent ATPases including MCM proteins involved in the initiation of eukaryotic DNA replication. Nucleic Acid Res. 1993;21:2541-2547.

Kumar D, Mukherji A, Saha S. Expresión and subcellular localization of Orc1 in Leishmania major. Bioch Biophys Res Commun. 2008;375(1):74-9.

Labib K, Diffley JF, Kearsey SE . G1 phase and B-type cyclins exclude the DNA-replication factor Mcm4 from the nucleus. Nature Cell Biol. 1999;1:415-422.

Labib K, Diffley JF . Is the MCM 2-7 complex the eukaryotic DNA replication fork helicase? Curr Opin Genet Dev. 2001;11:64-70.

Laemmli UK. Cleavage of structural proteins during the assembly of the heady of the bacteriophage T4. Nature.1970;227:680-685.

Lee C, Hong B, Choi JM, Kim Y, Watanabe S, Ishimi Y, Enomoto T, Tada S, Kim Y, Cho Y. Structural basis for inhibition of the replication licensing factor Cdt1 by Gemini. Nature. 2004;430:913-917.

Lee DG, Bell SP . ATPases switches controlling DNA replication initiation. Curr Opin Cell Biol. 2000;12(3):280-285.

Lee MG, Van Der Ploeg LH. Transcription of protein-coding genes in trypanosomes br RNA polymerase I. Annu Rev Microbiol. 1997;51:463-489.

Lei M, Tye BK. Initiating DNA synthesis: from recruiting to activating the MCM complex. Journal of Cell Science 2009;114:1447:1454.

Lipford JR, Bell SP. Nucleosomes positioned by ORC facilitate the initiation of DNA replication. Mol Cell. 2001;7:21-30.

Li X, Zhao Q, Liao R, Sun P, Wu X. The SCF (Skp2) ubiquitin ligase complex interacts with the human replication licensing factor Cdt1 and regulates Cdt1 degradation. J Biol Chem. 2003;278:30854-30858.

Lundgren M, Anderson A, Chen L, Nilsson P, Bernarder R. Three replication origins in Sulfolobus species: Synchrous initiation of chromosome replication and asynchronous termination. Proc Natl Acad Sci USA. 2004;101:7046-7051. 
Matsunaga F, Forterre P, Ishino Y, Myllykallio H. In vivo interactions of archaeal Cdc6/ORC1 and minichromosome maintenance proteins with the replication origin. Proc Natl Acad Sci USA. 2001;98:11152-11157.

Matsunaga F, Glatigny A, Mucchielli-Giorgi MH, Agier N, Delacroix H, Marisa L, et al. Genomewide and biochemical analyses of DNA-binding activity of Cdc6/Orc1 and Mcm proteins in Pyrococcus sp. Nucleic Acid Res. 2007;35(10):3214-22.

Matthews KR. The developmental cell biology of Trypanosoma brucei. J Cell Sci. 2005; 118(2):283-290.

Mayer MG, Floeter-Winter LM. Pre-mRNA trans-splicing: from kinetoplastids to mammals, an easy language for life diversity. Mem Inst Oswaldo Cruz. 2005;100:501-513.

Mc Culloch R . Antigenic variation in African trypanosomes: monitoring progress. Trends Parasitology. 2004;20(3):117-121.

Mehra P, Biswas AK, Gupta A, Gourinath S, Chitnis CE, Dhar SK. Expression and characterization of human malaria parasite Plasmodium falciparum origin recognition complex subunit 1. Biochem Biophys Res Commun. 2005 Nov 25; 337(3):955-66.

Minter DM, Minter-Goedbloed E, Marsden PD, Miles MA, Macedo V . Domestic risk-factoran attempt to assess risk of infection with Trypanosoma cruzi in houses in Brazil. Trans $\mathrm{R}$ Soc Trop Med Hyg. 1973;67(2):290.

Myllykallio H, Lopez P, Lopez-Garcia P, Heilig R, Saurin W, Zivanovic Y, Philippe H, Forterre P. Bacterial mode of replication with eukaryotic like machinery in a hyperthermophilic archaeon. Science. 2000;288:2212-2215.

Muzi-Falconi M, Kelly TJ. Orp1, a member of the Cdc18/Cdc6 family of S-phase regulators, is homologous to a component of the origin recognition complex. Proc Natl Acad Sci USA. 1995;92:12475-12479.

Nacional Center for Biotechnology Information. GENBANK [Database]. Available from: http://www.ncbi.nlm.nih.gov [cited 2006 Mar 08].

Nardelli SC, Avila AR, Freund A, Motta MC, Manhães L, de Jesus TC, Schenkman S, Fragoso SP, Krieger MA, Goldenberg S, Dallagiovanna B . Small-subunit rRNA processome proteins are translationally regulated during differentiation of Trypanosoma cruzi . Eukaryot Cell. 2007;6(2):337-45.

Nett-Lovsey RM, Herbert AD, Sternberg MJ, Kelley LA. Exploring the extremes of sequence/structure space with ensemble fold recognition in the program Phyre. Proteins. 2008;70:611-625. 
Neuwald AF, Aravind L, Spouge JL, Koonin EV . AAA+: A class of chaperone-like ATPases associated with the assembly, operation and disassembly of protein complexes. Genome Res. 1999;9(1):27-43.

Newlon C S. Putting it all together: building a prereplicative complex. Cell. 1997;91:717-20.

Nguyen VQ, Co C, Li JJ. Cyclin-dependent kinases prevent DNA re-replication through multiple mechanisms. Nature. 2001;411:1068-1073.

Nishitani H, Lygerou Z, Nishimoto T, Nurse P . The Cdt1 protein is required to license DNA for replication in fission yeast. Nature. 2000;404:625-628.

Nishitani H, Taraviras S, Lygerou Z, Nishimoto T. The human licensing factor for DNA replication Cdt1 accumulates in G1 phase and is destabilized after initiation of S-phase. J Biol Chem. 2001;276:44905-44911.

Notredame C, Higgins DG, Heringa J. T-Coffee: A novel method for fast and accurate multiple sequence alignment. J Mol Biol. 2000;302(1):205-217.

Pucci B, De FM, Rocco M, Esposito F, De FM, Esposito L, et al . Modular organization of the Sulfolobus solfataricus mini-chromosome maintenance protein. J Biol Chem. 2007 Apr 27;282(17):12574-82.

Randell JC, Bowers JL, Rodriguez HK, Bell SP. Sequential ATP Hydrolysis by Cdc6 and Orc directs loading of the MCM 2-7 Helicase. Mol Cell. 2006 Jan.6;21(1): 29-39.

Robinson NP, Bell SD. Extrachromosomal element capture and the evolution of multiple replication origins in archaeal chromosomes. Proc Natl Acad Sci USA. 2007;104:5806-5811.

Robinson NP, Dionne I, Lundgren M, Marsh VL, Bernander R, Bell SD. Identification of two origins of replication in the single chromosome of the Archaeon Sulfolobus solfactaricus. Cell. 2004;116:25-38.

Robinson NP, Bell SD. Origins of DNA replication in the three domains of life. FEBS Letter. 2004;272:3757-3766.

Rowles A, Tada S, Blow JJ. Changes in association of the Xenopus origin recognition complex with chromatin on licensing of replication origins. J Cell Sci. 1999;112:2011-2018.

Schenkman S, Diaz C, Nussenzweig V. Attachment of Trypanosoma cruzi trypomastigotes to receptors at restricted cell surface domains. Exp Parasitol. 1991;72:76-86.

Shecthter DF, Ying CY, Gautier J. The intrinsic DNA helicase activity of Methanobacterium thermoautotrophicum delta $\mathrm{H}$ minichromosome maintenance protein. J Biol Chem. 2000; 275:15049-15059. 
Silber AM, Tonelli RR, Lopes CG, Cunha e Silva N, Torrecilhas ACT, Schumacher RI, Colli W, Alves MJM. Glucose uptake in the mammalian stages of T.cruzi. Mol Biochem Parasitol. 2009; 168(1):102-108.

Singleton MR, Morales R, Grainge I, Cook N, Isupov MN, Wigley DB. Conformational changes induced by nucleotide binding in Cdc6/ORC from Aeropyrum pernix. J Mol Biol. 2004,Oct 22;343(3):547-57.

Speck C, Chen Z, Li H, Stillman B. ATPase-dependent cooperative binding of ORC and Cdc6 to origin DNA. Nat Struct Mol Biol. 2005 Nov;12(11):965-71.

Speck C, Stillman B. Cdc6 ATPase activity regulates ORC x Cdc6 stability and the selection of specific DNA sequences as origins of DNA replication. J Biol Chem. 2007 Apr 20; 282(16):11705-14.

Stillman B. Origin recognition and the chromossome cycle. FEBS Lett. 2005;579:877-884.

Stuart KD, Schnaufer A, Ernst NL, Panigrahi AK. Complex management: RNA editing in trypanosomes. Trends Biochem Sci. 2005;30:97-105.

Structural Bioinformatic Group, Imperial College London [3D-PSSM e Phyre Server]. Available from: http://www.sbg.bio.ic.ac.uk/ 3dpssm/index2.html [cited 2006 Apr 15].

Swiss Institute of Bioinformatics, Expasy Proteomics Server [Scan Prosite]. Available from: http://www.expasy.org/scanprosite [cited 2006 Apr 15].

Tada S, Li A, Maiorano D, Mechali M, Blow JJ.Repression of origin assembly in metaphase depends on inhibition of RLF-B/Cdt1 by geminin. Nature Cell Biol. 2001;3,107-113.

Tatsumi Y, Tsurimoto T, Shirahige K, Yoshikawa H, Obuse C. Association of human origin recognition complex 1 with chromatin DNA and nuclease resistant nuclear structures. J Biol Chem. 2000;275:5904-5910.

Teixeira SM. Control gene expression in Trypanosomatida. Braz J Med Biol Res. 1998;31: 503-516.

Thompson JD, Higgins DG, Gibson TJ. Clustal W: Improving the sensitivity of progressive multiple sequence alignment through sequence weighting, positions-specific gap penalties and weight matrix choice. Nucleic Acids Res. 1994;22:4673-4680.

Tsakraklides V, Bell S. Dynamics of pre-replicative complex assembly. J Biol Chem. 2010 Mar 26;285(13):9437-43.

The Institute for Genomic Research, J. Craig Venter Institute, USA [TIGR Database]. Available from: http://www.jcvi.orf (antigo www.tigr.org) [cited 2006 Mar 15]. 
Ullu E, Tschudi C. Trans-splicing in trypanosomes requires methylation of the 5' end of the spliced leader RNA. Proc Natl Acad Sci USA. 1991;88:10074-10078.

Ullu E, Tschudi C, Chakraborty T. RNA interference in protozoan parasites. Cell Microbiol. 2004;6(6):509-519.

Vas A, Mok W, Leatherwood J. Control of DNA rereplication via Cdc2 phosphorylation sites in the origin recognition complex. Mol Cell Biol. 2001;21:5767-5777.

Walker JE, Saraste M, Runswick MJ, Gay NJ. Distantly related sequences in the alpha- and beta-subunits of ATP synthase, myosin, kinases and other ATP-requiring enzymes and a common nucleotide binding fold. EMBO J. 1982;1(8):945-51.

Wickstead B, Ersfeld K, Gull K. Targeting of a tetracycline-inducible expression system to the transcriptionally silent minichromosomes of Trypanosoma brucei. Mol Biochem Parasitol. 2002;125:211-216.

Wirtz E, Leal S, Ochatt C, Cross GA. A tightly regulated inducible expression system for conditional gene knock-outs and dominant-negative genetics in Trypanosoma brucei. Mol Biochem Parasitol. 1999;99:89-101.

Woodward R, Gull K. Timing of nuclear and kinetoplast DNA replication and early morphological events in the cell cycle of Trypanosoma brucei. J Cell Sci. 1990;95(1):49-57.

World Health Organization. Technical Report Series. Control of Chagas Disease. Genova 2002. WORLD HEALTH ORGANIZATION - WHO [Dados epidemiológicos]. Available from: http://www.who.int [cited 2010 Feb 20].

World Health Organization [Dados obtidos da Doença do Sono]. Available from: http://www.who.int/mediacentre/factssheets/fs259/en/ [cited 2010 Apr 10].

Woese CR, Fox GE. Phylogenetic structure of the prokaryotic domain: the primary kingdoms. Proc Natl Acad Sci USA. 1977 Nov;74(11):5088-90.

Wuarin J, Buck V, Nurse P, Millar JB. Stable association of mitotic cyclin B/Cdc2 to replication origins prevents endoreplication. Cell. 2002;111:419-431. 